\title{
An approach to the use of indices-based analysis subject to money laundering and terrorist financing national risk assessment
}

Sergii Dmytrov

Doctor of Engineering, Professor, Member of Management Board, Head of Financial Monitoring Department, Bank Credit Dnepr PJSC, Ukraine

\section{Tetiana Medvid}

Ph.D., National Bank of Ukraine, Ukraine

(C) The Authors, 2017. This article is published with open access at ARMG Publishing.

\begin{abstract}
The core aim of this study is to propose an approach to quantitate estimation of indices-based information subject to necessities of the National Risk Assessment (NRA) of money laundering and terrorist financing (ML/TF) risks. Mathematical formalization analysis for Ukraine based on 11 indices and indicators for years 2011-2015 subject to core areas of the overall situation in a country considered within its National Risk Assessment was carried out.

Authors' contribution covers scientific novelty that is a first-time analysis of a general situation in a jurisdiction in light of the National Risk Assessment's requirements based on joint consideration of various indices and setting priority to areas of the overall country's situation in the framework of conducted calculations.

It was concluded that proposed approach is a valuable instrument for assessing priority of areas of the overall situation in the country for the National Risk Assessment's purposes through a formalized mechanism ensuring high objectiveness.

Practical significance of this study is a possibility to reach higher efficiency in allocation of available resources for the participants of the National Risk Assessment, to reduce some costs considering flexibility of the approach allowing consideration of significant volumes of information, its updating and comparison. This research could become a starting point for further research. Considering complexity of existing indices, there is a necessity to study a mechanism of their correlation and mutual influence, analyze elasticity and joint behavior, and discover the areas of preferable influence on large range of purposes not only limited to the MRA of ML/TF risks.
\end{abstract}

Keywords: national risk assessment, money laundering, terrorist financing, risks, indices.

JEL Classification: F50.

\section{Introduction}

Nowadays jurisdictions all over the world face with a necessity of holding a National Risk Assessment (NRA) of the money laundering and terrorist financing (ML/TF) risks subject to the requirements set in the FATF Recommendation [1]. The NRA shall provide reasons and facts comprehensive enough to ensure a distribution of powers and resources at the national level in accordance with clear and current understanding of the ML/TF risks. Herewith, the inherent level of existing ML/TF risks in a country is inseparably associated with its general situation. Consequently, understanding of general situation including political, economic, social stability etc. for any jurisdiction is an integral part of its NRA. Obviously, that in the course of the NRA, it is necessary to estimate the overall position of a country and perform it in the most efficient way spending minimum efforts and resources and providing a reliable conclusions. Existing indices and indicators cover the variety of issues allowing to have quantitate estimates of any area e.g., political stability, peace, terrorism, corruption, economic environment and social development, etc. These modern indices come from profound scientific studies and rely on knowledge, comprehensive data and up-to-date methodology. Therefore, they could serve a valuable source of information to assess an overall situation of a country. The main aim of our study is to develop an approach for indices-based analysis subject to certain tasks of the NRA of the ML/TF risks. 


\section{Literature review}

This topic attracted our attention in the course of further research of the AML/CFT issues started in 2008, in particular, in the course of study of application of mathematical modelling methods for NRA. It became clear that indices-based analysis for the NRA could strengthen the prioritization of findings.

Though the issue of the NRA of the ML/TF risks very often is covered by the reports and guidance of international organizations such as FATF [1, 4], OSCE [14], IMF [15] the World Bank [15], a range of approaches are to be considered. First, micro- and macroeconomic models on ML developed by number of researchers, including Donato Masciandaro [17, 18, 19, 20]. These microeconomic models are based in particular on the construction of utility function for criminals (including the use of elements of portfolio theory) and macroeconomic models usually aimed at determining the exposure (shares) of criminal sector in economy and their interpenetration and international expand. Secondly, let us bring your attention to interregional input-output model proposed by John Walker [16] and gravity model of Brigitte Unger [22] based on estimations of amounts derived from crime laundering which are mediated by certain countries. The World Bank approach is based on Bayesian network for assessing vulnerability of national AML/CTF systems [16] and the IMF approach is based on calculating the risk probability of successful legalization of funds received crime or financing of terrorism in certain countries adjusted by consequences of these events.

Authors would like to bring your attention to the tools of the World Bank that provide assessment of certain areas in the overall position of a jurisdiction as political, economic, geographical and institutional environment at the national level. The assessment of the mentioned factors shall be backed by relevant information though there are no restrictions or minimum required sources of information to be considered. The tool of both first and second generation requires users to give subjective judgments considering such information. It is a disputable issue because two aims are expected be reached at once: from one hand, flexibility of assessment and consideration of expertise are essential and, from the other hand, objectiveness and possibility to update and compare the estimations are required.

Herewith, a group of researchers leaded also by Brigitte Unger [23] proposes an interesting approach to clustering countries considering the AML/CFT issues by hierarchical agglomerative cluster analysis with the Ward's algorithm. The clustering was performed basing on 29 indicators including two World Bank indices: the index of government effectiveness and the index of corruption. There were considered minimum value, maximum value, mean and standard deviation of the indicators.

So, a need for appropriate utilization of indices-based information exists and there are attempts to applicate them for NRA of ML/TF risks. At the same time, this issue is sensible due to numerous requirements and complexity of the nature of indices.

National methodologies of NRA are basically adopted in legal documents such as laws and by-laws but these are documents with restricted access. Partially, several features of the approach applied are given in the public NRA reports. NRA public reports of Ireland, Ukraine, Canada, United Kingdom, Japan, Malaysia and Singapore [5, 6, $7,8,9,11,12,13$ ] became valuable sources of information for this study demonstrating attempts of certain jurisdictions in Singapore and Ukraine in particular to utilize indices-based analysis for NRA. From the other hand, $\mathrm{UK}$, at the final stage of its NRA while evaluating the relative exposure of each sector to risk, amended its model to reduce the dependency on quantitative data and include factors for qualitative assessment.

\section{Methodology}

In the course of this study the methods of analysis and synthesis (to justify the necessity of indices-based analysis for assessment of an overall situation in a jurisdiction subject to the NRA purposes), system generalization (to determine the nature and identify areas for assessment of overall position of Ukraine concerning its NRA of ML/TF risks), comparative analysis (to determine the features of the actual approaches to NRA of certain jurisdictions) were applied.

Means of visualization were applied to quantitative data for figures of 11 indices for the period from 2011 to 2015 year to analyze the dynamics, fluctuations and position of their medians and figures for Ukraine by reference to minimum and maximum values. In addition, a histogramming was performed to group the indices concerning figures of their arithmetic means of absolute increases in lacking proportions in Ukraine.

Statistical methods for structural analysis such as, mean, median, proportion and a performance indicator that is an absolute increment were applied for joint analysis of figures of 11 indices as for Ukraine. Composing a dataset for analysis, authors faced with the lack of some figures that is why the simulation methods were applied to substitute missing data. 


\section{Results of research}

To perform an effective NRA of ML/FT risks, it is necessary to develop an effective methodological apparatus allowing to carry out impartial, comprehensive and adequate assessment of the situation. Each jurisdiction conducts the NRA subject to its own methodology and no single approach exists. Thus, FATF provided the following general principles for the NRA conducting [4].

The first principle: the NRA contributors shall agree clearly on its purposes. It means, in particular, an obligation to identify, assess, and understand ML/TF risks for the country, and take action and apply resources to ensure the risks are mitigated properly. The core issue of this principle is a provision of an efficient allocation of resources across the AML/CFT regime and the implementation of risk-based efforts throughout the FATF recommendations. Jurisdictions are required to understand the ML/TF risks on their national level and manage discovered risks proportionately.

The second principle: it is necessary to determine the scope of NRA. Different types of assessments are allowed for applying and combining to reach a national-level understanding of the ML/TF risks. Herewith, the FATF encourages attempts to consider macro-level risks influencing the AML/CFT regime. FATF provided examples of factors that may be regarded for the assessment of overall situation in the country including political, economic, social, technological, environmental and geographical, as well as legislative factors.

The third principle requires that the NRA assessment shall be comprehensive. FATF strongly recommends the jurisdictions to provide enough relevant assessment of ML/TF risk based on sufficient analysis of possible threats and vulnerabilities as well as their consequences.

The last principle states that it is essential to have a high-level commitment subject to the assessment of appropriate risks. Officials of any jurisdiction shall recognize the ML/TF risks existing within their country. They are required to understand and acknowledge any of such risks.

The analysis of the publicly available NRA reports and releases of several jurisdictions (see Table 1 in Appendix) $[5,6,7,8,9,12,13]$ gives us a possibility to conclude that very often NRA covers the following areas of the overall situation in a country: geopolitical, governance and legal framework, social and economic factors. Corruption and terrorism are of great importance and paid significant attention by the jurisdictions. The areas defined in Table 1 were considered by the countries not necessarily separately. Very often corruption is covered within the analysis of political or economic environment as well as one of types of criminal activity, for example, Singapore, Ukraine and Ireland consider corruption as a component of their political environment but Canada assesses it as a separate overall money laundering threat.

It is obvious that a comprehensive analysis of the abovemenioned areas require significant resources and efforts at a country level. However, it is not the key focus but either an essential part for NRA of the ML/TF risks.

Herewith, many different indices, indicators and ratings cover the variety of areas allowing to have quantitate estimates of political stability, peace, terrorism, corruption, economic environment and social development, etc. These modern indices come from profound scientific studies and rely on knowledge, comprehensive data and up-to-date methodology. For example, the Global Terrorism Index built by the Institute for Economics and Peace is based on data from the Global Terrorism Database maintained by the National consortium for the study of terrorism and responses to terrorism at the University of Maryland. This database is recognized to be the most valuable source of information on terrorist activity globally and covers over 140000 terrorist incidents [2]. The next example is the State Fragile Index developed by the Fund for Peace produced through the application of the Fund's own analytical platform called Conflict Assessment System Tool and backed by analysis of millions of documents every year. The countries are ranked considering twelve key political, social and economic indicators that are based themselves on over 100 sub-indicators [3]. Given examples prove that recognized and reputable indices could be considered as a valuable source of information for the NRA.

At the same time, the utilization of indices and indicators of any kind requires deep understanding of their nature and methodology. Once decided upon utilization of a set of certain indices, anyone would face such challenges as random number of indices for each area, various methodologies for calculation of indices, diversity of scales, etc. As the result, it is impossible to make enough objective conclusions based on figures of various indices for a jurisdiction without their bringing to a single scale based exceptionally on subjective expertise. Moreover, the NRA shall be performed periodically and it is extremely hard to study the dynamics and perform any comparison analysis based on subjective assessments of number of experts. 
Therefore, this study is an attempt to develop an approach for indices-based analysis subject to certain tasks of the NRA of the ML/TF risks. For this purpose it was decided to conduct analysis in Ukraine concerning already defined core areas of the overall situation in a country considered within its NRA.

At the first stage a range of indices and indicators credible from our point of view (see Table 2 in Appendix) were chosen. Besides indices given in Table 2 there is only one absolute indicator. Illicit financial flows from developing countries are measured in million US dollars [11]. To bring the measurement of this indicator in line with the spirit of the rest chosen indices, the percentage of the volume of illicit flows to the GDP [10] by countries was calculated. Hereinafter the authors consider the percentage of the illicit flow to GDP.

At the second stage a dataset containing actual maximum, minimum values and values for Ukraine of the listed in the table 2 indices and indicators for the years 2011-2015 [11, 24, 25, 26, 27, 28, 29, 30, 32, 34, 35, $36,37,38,39,40,41,42]$ was formed. While composing this dataset, authors faced with a lack of some figures, that's why the missing figures were simulated. The volumes of illicit financial flows from developing countries are available for the years 2004-2013 [11]. To simulate data for 2014 and 2015, average minimum, maximum and median for 9 years period from 2004 and 2013 were calculated. The figure on the volume of illicit flows from Ukraine for 2015 was taken from a mass media publication [31] and an appropriate figure for 2014 was calculated as an average for 2013 and 2015. The Basel AML Index is calculated staring from 2012, so the figures for Ukraine, median, minimum and maximum for 2011 were calculated as an average for 5 years from 2012 to 2016. The figures of the Human Development Index for 2015 were calculated as averages for 2011-2014. The figures of the Global Terrorism Index for 2012 were calculated as averages for 2011 and 2013. The scale for the Corruption Perception Index was changed in 2012 for the one from 0 to 100, before it was from 0 to 10 . That is why the figures of this index for 2011 were multiplied by 10 to make them comparable with the rest.

The main challenge resaerchers faced on this stage was choosing a single approach to measure existing position of Ukraine comparing to the rest jurisdictions ranked. Also, there were the challenges already mentioned before: the indices developed upon various methodologies, they cover random number of jurisdictions, their scales are different and they are correlated to some extent. So, it was decided to calculate a median for each index and indicator from our list to understand which estimations are typical for the whole number of jurisdictions ranked (see Table 3 in Appendix).

At the third stage a visualization by each index from the dataset (see Figures from 1 to 11 in Appendix) was performed. Considering the results of visualization it is possible to distinguish several trends. For Doing Business, the Economic Freedom Index and the Global Competitiveness Index, the Basel AML Index - the median is nearly equals the mean. The limits of fluctuation of correspondence of median to mean vary from 0.9859 to 1.0105 . The medians of the Fragile States Index, the International Property Rights Index and the Corruption Perception Index are shifted toward the worst meanings. Medians of the Global Terrorism Index, the Global Peace Index and the Human Development Index are shifted to the best figures. The most fluctuant appeared to be ratio of the volume of illicit flows from developing countries to their GDP. On average its median counts for $4.58 \%$ and the minimum always equals to zero for 2011-2015. Herewith, the maximum varies from $714.29 \%$ in 2011 to $131.4 \%$ in 2013 in a random manner. To our point of view, medians of the considered indices are quantitate estimations of the most likely situation in the majority of countries rated.

At the fourth stage the analysis of Ukraine's situation considering the median of the indices was conducted. Authors took the medians as average thresholds throughout ranked countries according to the principle that such average for most countries shall be a kind of required minimum. Then figures for Ukraine were compared with the medians. All the indexes from our dataset were considered according to their scales and divided into two types. The first type was designated to indices if their higher value means better result. The second type was designated to those which higher value means worse result (see Table 2 in Appendix). To find how much Ukraine lags behind / higher than the median there, for the $1^{\text {st }}$ type of indices ratios between the figure for Ukraine and the median and for the $2^{\text {nd }}$ type of indices ratios between median and figure for Ukraine were calculated. The calculated figures were deducted from 1 to measure proportions lacking for Ukraine to reach in fact the most likely situation in the majority of countries. Then absolute increases in lacking proportions in comparison with the first reference period of 2011 by each index and arithmetic means of these increments (see Table 4 in Appendix) were calculated.

At the fifth stage a histogram was built on the basis of arithmetic mean of absolute increases in lacking proportions by each index (see Figure 12). Analyzing this visualization, it is possible to split indices into four 
main groups concerning Ukraine. The first group of indices includes those on which Ukraine demonstrated the biggest gap increase between its ranks and the average thresholds (median) throughout ranked countries in the negative meaning. These are the Global Peace Index, the Corruption Perception Index and the Global Terrorism Index. Such outcomes are expected due to escalation of external aggression for Ukraine in 20142015. Moreover, the existence of strong correlation between corruption and peace [44] is already proved. According to Transparency International, 5 of the 10 countries with the highest levels of corruption are also among the 10 least peaceful countries on the globe [43]. The second group of indices includes the Fragile States Index, the International Property Rights Index and the Ratio of Illicit flows to GDP on which Ukraine demonstrated slight negative growth. The third group covers the Index of Economic Freedom, the Human Development Index and the Basel AML Index that kept stable with no sizeable changes as a whole. And the last fourth group includes the indices on which Ukraine had negative average absolute increase in lacking proportions meaning that it has improved its position on such indices. These are the Global Competitiveness Index and the Doing Business.

For the purposes of the NRA, it is necessary to define the priority of certain areas of the overall situation in a country. When we started analysis for Ukraine the indices and indicators in our dataset were distributed among the following key areas (see Table 2 in Appendix): geopolitical situation, governance and legal framework, economic and social development, terrorism and corruption. To define the priority of the area considering both the quantity of indices and average absolute increase in lacking proportions of each index for area, an average score for each area (see Table 5 in Appendix) reflecting an overall priority of the area was calculated. The lower the score, the higher priority of the area shall be.

Subject to our calculations for Ukraine performed on the dataset containing figures by 11 indices and indicators for years 2011-2015, the levels of areas priority at the national level for the purposes of the NRA of ML/TF risks were defined. The following areas were designated as the most vulnerable areas considering an average absolute increase in proportions lacking (measured in the negative meaning) for Ukraine to reach the most likely situation in the majority of ranked countries: terrorism, corruption and geopolitical situation.

\section{Conclusions}

The necessity to consider the general situation in the country when concluding on findings of the NRA and deciding on allocation of available resources for mitigation of the discovered ML/TF risks in a jurisdiction requires appropriate techniques. Such techniques shall be both comprehensive and flexible. Herewith, if they will allow regular (periodical) monitoring of the situation, it will be a plus. Proposed approach gives a possibility to analyze a wide range of information represented though various indices, ratings and indicators already based on extended data and comprehensive analysis. It allows determining priorities for considered areas of the overall situation in a jurisdiction based on objective calculations. Participants of the NRA of the ML/TF risks could benefit using such approach. The participants of the NRA should decide themselves on the list or areas and indices to be considered. The existance of a single methodology for indices-based analysis makes the results clear for every participant. Also, the approach ensures possibility to update information when necessary. Consequently, such approach could ensure an efficient utilization of available resources and provide a technique for consideration of significant volume of information.

\section{References}

1. The FATF Recommendations. The FATF (2012). Retrieved from http://www.fatf-gafi.org/media/fatf/documents/recommendations/pdfs/FATF_Recommendations.pdf.

2. Global Terrorism Index Report (2015). Institute for Economics \& Peace. November 2015. p. 2. Retrieved from http://162.243.170.40/assets/2015\%20Global\%20Terrorism\%20Index\%20Report_2.pdf.

3. The Methodology behind the Index. The Fund for Peace. Retrieved from http://fsi.fundforpeace.org/methodology.

4. Guidance on National Risk Assessment. The FATF (February 2013). Retrieved from http://www.fatfgafi.org/media/fatf/content/images/National_ML_TF_Risk_Assessment.pdf.

5. National Risk Assessment report on preventing and countering legalization (laundering) of proceeds of crime and financing of terrorism 2016. The State Financial Monitoring Service of Ukraine. Retrieved from http://www.sdfm.gov.ua/content/file/Site_docs/2017/20170113/nra.pdf.

6. Assessment of Inherent Risks of Money Laundering and Terrorist Financing in Canada (2015). Department of Finance of Canada. Retrieved from http://www.fin.gc.ca/pub/mltf-rpcfat/index-eng.asp. 
7. Malaysia's National Risk Assessment. Bank Negara Malaysia. Retrieved from http://amlcft.bnm.gov.my/document/Malaysia_NRA.pdf.

8. Singapore National Money Laundering and Terrorist Financing Risk Assessment Report (2013). Ministry of Home Affairs of Singapore. Ministry of Finance of Singapore. Monetary Authority of Singapore. Retrieved from http://www.mof.gov.sg/portals/0/data/cmsresource/Press\%20Release/2013/Singapore\%20NRA\%20 Report.pdf.

9. National Risk Assessment for Ireland. Money laundering and terrorist financing. The AMLSC. Retrieved from http://www.finance.gov.ie/sites/default/files/NRA\%20FINAL\%20for\%20Publication.pdf.

10. The World Bank Database. Retrieved from http://data.worldbank.org/.

11. Illicit Financial Flows from Developing Countries: 2003-2014. Global Financial Integrity. Retrieved from http://www.gfintegrity.org/report/illicit-financial-flows-from-developing-countries-2004-2013/.

12. UK National Risk Assessment of Money Laundering and Terrorist Financing 2015. HM Treasury. Home Office. Retrieved from https://www.gov.uk/government/uploads/system/uploads/ attachment_data/file/468210/UK_NRA_October_2015_final_web.pdf.

13. National Risk Assessment of Money Laundering and Terrorist Financing. December 2014. Working Group on the National Risk Assessment of Money Laundering and Terrorist Financing of Liaison Conference of Related Ministries and Agencies for Implementation of FATF Recommendations. Retrieved from https://www.npa.go.jp/sosikihanzai/jafic/en/nenzihokoku_e/data/jafic_e.pdf.

14. OSCE Handbook on Data Collection in Support of Money Laundering and Terrorism Financing, National Risk Assessments. Organization for Security and Co-operation in Europe. October 16, 2012. Retrieved from http://www.osce.org/eea/96398?download=true.

15. The International Monetary Fund Staffs' ML/FT National Risk Assessment Methodology. Retrieved from www.fatf-gafi.org/media/fatf/documents/reports/Risk_Assessment_IMF.pdf.

16. The World Bank Risk Assessment Methodology. Retrieved from www.fatf-gafi.org/media/fatf/ documents/reports/Risk_Assessment_World_Bank.pdf.

17. John Walker (1995). Modeling Global Money Laundering Flows - some findings.

18. Donato Masciandaro, Andrew W. Mullineux \& Victor Murinde (2003). Economics of Money Laundering: A Primer.

19. Masciandaro, D. (1998). Money Laundering Regulation: The Microeconomics. Journal of Money Laundering Control, 2(1), 49-58.

20. Masciandaro, D. (1996). Pecunia olet? Microeconomia del riciclaggio bancario e finanziario. Rivista Internazionale di Scienze Economiche e Commerciali, 43, 817-844.

21. Masciandaro, D., Takats, E., Unger, B. (2007). Black Finance. The Economics of Money. Edward Elgar, Cheltenham.

22. Unger et al.(2006).The Amounts and the Effects of Money Laundering, Report for the Ministry of Finance, Amsterdam. Retrieved from www.rijksoverheid.nl/bestanden/documenten-en-publicaties/rapporten/2006/02/16/onderzoeksrapport-the-amounts-and-the-effects-of-money-laundering/witwassen-in-nederland-onderzoek-naar-criminele-geldstromen.pdf.

23. Unger, B., Addink, H., Walker, J., Ferwerda, J., Van den Broek, M., Deleanu, I. (2013). Project 'ECOLEF' The Economic and Legal Effectiveness of Anti-Money Laundering and Combating Terrorist Financing Policy Final Report. Retrieved from http://www2.econ.uu.nl/users/unger/ecolef files/Final\%20ECOLEF\%20report\%20(digital\%20version).pdf.

24. Global Peace Index 2015. The Institute for Economics and Peace. Retrieved from http://economicsandpeace.org/wp-content/uploads/2015/06/Global-Peace-Index-Report-2015_0.pdf.

25. Global Peace Index 2014. The Institute for Economics and Peace. Retrieved from http://economicsandpeace.org/wp-content/uploads/2015/06/2014-Global-Peace-Index-REPORT_0-1.pdf.

26. Global Peace Index 2013. The Institute for Economics and Peace. Retrieved from http://economicsandpeace.org/wp-content/uploads/2013/06/2013-GPI-Report.pdf.

27. Global Peace Index 2012. The Institute for Economics and Peace. Retrieved from http://economicsandpeace.org/wp-content/uploads/2015/06/2012-Global-Peace-Index-Report.pdf.

28. Global Peace Index 2011. The Institute for Economics and Peace. Retrieved from http://economicsandpeace.org/wp-content/uploads/2015/08/2011-GPI-Results-Report.pdf.

29. The Fragile States Index Data. The Fund for Peace. Retrieved from http://fsi.fundforpeace.org/data.

30. Basel AML Index. BaselInstitute on Governance. Retrieved from https://index.baselgovernance.org/ranking.

31. Yuliya Tymoshenko: Ukrayina na tretiomu mistsi v sviti po vidmyvannyu hroshey cherez ofshory. Fact Check [Ukraine takes the third place in the world by money laundering through offshore. Fact Check]. Reitrieved 
from https://www.factcheck.com.ua/ua/yuliya-timoshenko-ukraina-na-tretem-meste-v-mire-po-otmyvaniyudeneg-cherez-offshory/.

32. World Rankings - International Property Rights Index - countries ranking (2015, 2012-2008). Reitrieved from https://knoema.com/atlas/topics/World-Rankings/World-Rankings/International-Property-Rights-Index.

33. International Property Rights Index, 2014 (2014-2012). Reitrieved from https://knoema.com/IPRI2014Dec/international-property-rights-index-2014?action=download\#.

34. The Global Competitiveness Index historical dataset. World Economic Forum. Retrieved from www3.wefrum.org/docs/GCR2014-15/GCI_Dataset_2006-07-2014-15.xlsx.

35. Doing Business. World Bank. Retrieved from http://russian.doingbusiness.org/Custom-Query.

36. Index of Economic Freedom. The Heritage Foundation. Retrieved from http://www.heritage.org/index/explore?view=by-region-country-year.

37. Human Development Index. United Nations Development Programme. Retrieved from http://hdr.undp.org/en/content/human-development-index-hdi.

38. Global Terrorism Index 2016. The Institute for Economics and Peace. Retrieved from http://economicsandpeace.org/wp-content/uploads/2016/11/Global-Terrorism-Index-2016.2.pdf.

39. Global Terrorism Index 2015. The Institute for Economics and Peace. Retrieved from http://economicsandpeace.org/wp-content/uploads/2015/11/Global-Terrorism-Index-2015.pdf.

40. Global Terrorism Index 2014. The Institute for Economics and Peace. Retrieved from http://economicsandpeace.org/wp-content/uploads/2015/06/Global-Terrorism-Index-Report-2014.pdf.

41. Global Terrorism Index 2012. The Institute for Economics and Peace. Retrieved from http://reliefweb.int/sites/reliefweb.int/files/resources/2012-Global-Terrorism-Index-Report.pdf.

42. Corruption Perception Index. Transparency International. Retrieved from http://www.transparency.org/cpi2015\#downloads.

43. Corruption Perception Index 2015. Transparency International. Retrieved from http://www.transparency.org/cpi2015.

44. Corruption as a threat to stability and peace. Transperency International. 2014. Retrieved from http://tidefence.org/publications/corruption-as-a-threat-to-stability-and-peace/.

\section{Appendices}

Table 1. Core areas of the overall situation in a country considered within the NRA of ML/TF risks

\begin{tabular}{|c|c|c|c|c|c|}
\hline $\begin{array}{l}\text { Country, year of } \\
\text { NRA report / } \\
\text { release }\end{array}$ & \multicolumn{5}{|c|}{ Areas considered } \\
\hline 1 & 2 & 3 & 4 & 5 & 6 \\
\hline Ireland (2016) & $\begin{array}{l}\text { Geographical, po- } \\
\text { litical environ- } \\
\text { ment }\end{array}$ & $\begin{array}{l}\text { Legal, judicial and in- } \\
\text { stitutional framework } \\
\text { for AML/CFT }\end{array}$ & $\begin{array}{l}\text { Economic } \\
\text { environment }\end{array}$ & Terrorism & Corruption \\
\hline Ukraine (2016) & $\begin{array}{l}\text { Political stability, } \\
\text { peace }\end{array}$ & $\begin{array}{l}\text { Governance and } \\
\text { legal framework for } \\
\text { AML/CFT }\end{array}$ & $\begin{array}{l}\text { Economic development } \\
\text { and social issues }\end{array}$ & Terrorism & Corruption \\
\hline Canada (2015) & $\begin{array}{l}\text { Geopolitical } \\
\text { situation }\end{array}$ & $\begin{array}{l}\text { Governance and legal } \\
\text { framework for } \\
\text { AML/CFT }\end{array}$ & $\begin{array}{l}\text { Socio-economic fea- } \\
\text { tures }\end{array}$ & Terrorism & Corruption \\
\hline $\begin{array}{l}\text { United Kingdom } \\
(2015)\end{array}$ & - & $\begin{array}{l}\text { Legal and regulatory } \\
\text { framework governing } \\
\text { AML/CFT regime }\end{array}$ & $\begin{array}{l}\text { International ML threats } \\
\text { including UK's status as } \\
\text { a global financial center }\end{array}$ & $\begin{array}{l}\text { Terrorist } \\
\text { financing }\end{array}$ & $\begin{array}{l}\text { PEPs, interna- } \\
\text { tional corrup- } \\
\text { tion cases }\end{array}$ \\
\hline Japan (2014) & $\begin{array}{l}\text { Geographic } \\
\text { environment }\end{array}$ & AML/CFT regime & $\begin{array}{l}\text { Economic } \\
\text { environment }\end{array}$ & $\begin{array}{l}\text { Terrorist fi- } \\
\text { nancing }\end{array}$ & PEPs \\
\hline Malaysia (2013) & Geographical & $\begin{array}{l}\text { Legal (mainly for } \\
\text { AML/CFT) }\end{array}$ & Economy & Terrorism & Corruption \\
\hline Singapore (2013) & $\begin{array}{l}\text { Geographical, po- } \\
\text { litical environ- } \\
\text { ment }\end{array}$ & $\begin{array}{l}\text { Legal, judicial and in- } \\
\text { stitutional framework } \\
\text { (mainly for } \\
\text { AML/CFT) }\end{array}$ & $\begin{array}{l}\text { Economic } \\
\text { environment }\end{array}$ & Terrorism & Corruption \\
\hline
\end{tabular}


Table 2. The list of considered indices and ratings

\begin{tabular}{|c|c|c|c|}
\hline $\begin{array}{c}\text { Area assessed by the index / } \\
\text { indicator }\end{array}$ & Name of index / indicator & Type & Developer of the index / indicator \\
\hline 1 & 2 & 3 & 4 \\
\hline \multirow{2}{*}{ Geopolitical situation } & Global Peace Index & II & Institute for Economics and Peace \\
\hline & Fragile States Index & II & The Fund for Peace \\
\hline \multirow{3}{*}{$\begin{array}{l}\text { Governance and legal } \\
\text { framework }\end{array}$} & Basel AML Index & II & The Basel Institute on Governance \\
\hline & $\begin{array}{l}\text { Illicit Financial Flows from De- } \\
\text { veloping Countries }\end{array}$ & II & Global Financial Integrity \\
\hline & $\begin{array}{l}\text { International Property Rights } \\
\text { Index }\end{array}$ & I & Property Rights Alliance \\
\hline \multirow{4}{*}{$\begin{array}{l}\text { Economic and social devel- } \\
\text { opment }\end{array}$} & Global Competitiveness Index & $\mathrm{I}$ & World Economic Forum \\
\hline & Doing Business & $\mathrm{I}$ & World Bank \\
\hline & Index of Economic Freedom & I & Wall Street Journal and Heritage Foundation \\
\hline & Human Development Index & I & United Nations Development Program \\
\hline Terrorism & Global Terrorism Index & II & Institute for Economics and Peace \\
\hline Corruption & Corruption Perception Index & I & Transparency International \\
\hline
\end{tabular}

Table 3. Actual maximum, minimum values, median and values for Ukraine of the given indices and indicators for 2011-2015

\begin{tabular}{|c|c|c|c|c|c|}
\hline Index / indicator & 2011 & 2012 & 2013 & 2014 & 2015 \\
\hline 1 & 2 & 3 & 4 & 5 & 6 \\
\hline \multicolumn{6}{|c|}{ Global Peace Index } \\
\hline Ukraine & 1.995 & 1.953 & 2.238 & 2.546 & 2.845 \\
\hline Actual Minimum Value & 1.148 & 1.113 & 1.162 & 1.189 & 1.148 \\
\hline Actual Maximum Value & 3.379 & 3.392 & 3.44 & 3.65 & 3.645 \\
\hline Median & 2.046 & 1.998 & 2.0545 & 2.0035 & 1.9875 \\
\hline \multicolumn{6}{|c|}{ Fragile States Index } \\
\hline Ukraine & 69 & 67.2 & 65.9 & 67.2 & 76.3 \\
\hline Actual Minimum Value & 19.7 & 20 & 18 & 18.7 & 17.8 \\
\hline Actual Maximum Value & 113.4 & 114.9 & 113.9 & 112.9 & 114.5 \\
\hline Median & 76 & 75.1 & 75.2 & 75.1 & 74.6 \\
\hline \multicolumn{6}{|c|}{ Basel AML Index } \\
\hline Ukraine & 6.554 & 6.62 & 6.47 & 6.55 & 6.56 \\
\hline Actual Minimum Value & 2.724 & 2.36 & 3.17 & 2.51 & 2.53 \\
\hline Actual Maximum Value & 8.576 & 8.57 & 8.55 & 8.56 & 8.59 \\
\hline Median & 5.81 & 5.75 & 5.86 & 5.84 & 5.79 \\
\hline \multicolumn{6}{|c|}{ Illicit Financial Flows from Developing Countries (to GDP, \%) } \\
\hline Ukraine & $11 \%$ & $11.95 \%$ & $7.59 \%$ & $10.53 \%$ & $15.67 \%$ \\
\hline Actual Minimum Value & $0 \%$ & $0 \%$ & $0 \%$ & $0 \%$ & $0 \%$ \\
\hline Actual Maximum Value & $714.29 \%$ & $252.08 \%$ & $131.4 \%$ & $344.83 \%$ & $344.83 \%$ \\
\hline Median & $4.64 \%$ & $4.96 \%$ & $3.68 \%$ & $4.82 \%$ & $4.82 \%$ \\
\hline \multicolumn{6}{|c|}{ International Property Rights Index } \\
\hline Ukraine & 4 & 4 & 4.2 & 4.3 & 3.9 \\
\hline Actual Minimum Value & 2.5 & 2.85 & 2.85 & 3.2 & 2.5 \\
\hline Actual Maximum Value & 8.65 & 8.6 & 8.6 & 8.5 & 8.9 \\
\hline Median & 5.1 & 5.2 & 5.2 & 5.3 & 5.3 \\
\hline \multicolumn{6}{|c|}{ Global Competitiveness Index } \\
\hline Ukraine & 3.901 & 4 & 4.139 & 4.052 & 4.139 \\
\hline Actual Minimum Value & 2.732 & 2.87 & 2.779 & 2.851 & 2.793 \\
\hline Actual Maximum Value & 5.630 & 5.737 & 5.722 & 5.666 & 5.704 \\
\hline Median & 4.139 & 4.186 & 4.141 & 4.13 & 4.198 \\
\hline
\end{tabular}


Table 3 (cont.). Actual maximum, minimum values, median and values for Ukraine of the given indices and indicators for 2011-2015

\begin{tabular}{|c|c|c|c|c|c|}
\hline Index / indicator & 2011 & 2012 & 2013 & 2014 & 2015 \\
\hline \multicolumn{6}{|c|}{ Doing Business } \\
\hline Ukraine & 44.21 & 44.35 & 48.87 & 58.14 & 61.83 \\
\hline Actual Minimum Value & 27.51 & 31.62 & 31.7 & 32.06 & 26.4 \\
\hline Actual Maximum Value & 90.4 & 90.41 & 90.38 & 91.24 & 86.7 \\
\hline Median & 60.04 & 60.51 & 61.91 & 62.34 & 60.6 \\
\hline \multicolumn{6}{|c|}{ Index of Economic Freedom } \\
\hline Ukraine & 46.9 & 49.3 & 46.3 & 46.1 & 45.8 \\
\hline Actual Minimum Value & 1 & 1 & 1.5 & 1 & 1.3 \\
\hline Actual Maximum Value & 89.7 & 89.9 & 89.3 & 90.1 & 89.6 \\
\hline Median & 60 & 60.1 & 59.6 & 60 & 60.1 \\
\hline \multicolumn{6}{|c|}{ Human Development Index } \\
\hline Ukraine & 0.738 & 0.743 & 0.746 & 0.747 & 0.744 \\
\hline Actual Minimum Value & 0.333 & 0.342 & 0.345 & 0.348 & 0.342 \\
\hline Actual Maximum Value & 0.941 & 0.942 & 0.942 & 0.944 & 0.942 \\
\hline Median & 0.7155 & 0.7205 & 0.7225 & 0.724 & 0.720625 \\
\hline \multicolumn{6}{|c|}{ Global Terrorism Index } \\
\hline Ukraine & 2.16 & 2.555 & 2.95 & 7.2 & 7.133 \\
\hline Actual Minimum Value & 0 & 0 & 0 & 0 & 0 \\
\hline Actual Maximum Value & 9.56 & 9.78 & 10 & 10 & 9.96 \\
\hline Median & 0.99 & 1.0425 & 1.095 & 1.993 & 1.631 \\
\hline \multicolumn{6}{|c|}{ Corruption Perception Index } \\
\hline Ukraine & 27 & 26 & 25 & 26 & 27 \\
\hline Actual Minimum Value & 10 & 8 & 8 & 8 & 8 \\
\hline Actual Maximum Value & 95 & 90 & 91 & 92 & 91 \\
\hline Median & 32 & 37 & 38 & 38 & 37 \\
\hline
\end{tabular}

Table 4. Proportions lacking for Ukraine to reach median of indices and their absolute increase

\begin{tabular}{|l|c|c|c|c|c|c|c|c|c|c|}
\hline \multirow{2}{*}{ Indices } & \multicolumn{3}{|c|}{ Proportions lacking for Ukraine to reach median } & \multicolumn{3}{c|}{$\begin{array}{c}\text { Absolute increase in comparison with first } \\
\text { reference period of 2011 }\end{array}$} & $\begin{array}{c}\text { Average abso- } \\
\text { lute increase }\end{array}$ \\
\cline { 2 - 12 } & 2011 & 2012 & 2013 & 2014 & 2015 & 2012 & 2013 & 2014 & 2015 & 10 \\
\hline \multicolumn{1}{|c|}{1} & 2 & 3 & 4 & 5 & 6 & 7 & 8 & 9 & 11 \\
\hline $\begin{array}{l}\text { Global Peace In- } \\
\text { dex }\end{array}$ & -0.0256 & -0.0230 & 0.0820 & 0.2131 & 0.3014 & 0.0025 & 0.1076 & 0.2386 & 0.3270 & 0.1689 \\
\hline $\begin{array}{l}\text { Fragile States In- } \\
\text { dex }\end{array}$ & -0.1013 & -0.1168 & -0.1418 & -0.1176 & 0.0223 & -0.0155 & -0.0405 & -0.0163 & 0.1236 & 0.0128 \\
\hline Basel AML Index & 0.1135 & 0.1314 & 0.0943 & 0.1084 & 0.1174 & 0.0179 & -0.0192 & -0.0051 & 0.0039 & -0.0006 \\
\hline $\begin{array}{l}\text { Illicit flows to } \\
\text { GDP, \% }\end{array}$ & 0.5782 & 0.5850 & 0.5148 & 0.5424 & 0.6926 & 0.0068 & -0.0635 & -0.0358 & 0.1143 & 0.0055 \\
\hline $\begin{array}{l}\text { International } \\
\text { Property Rights } \\
\text { Index }\end{array}$ & 0.2157 & 0.2357 & 0.1975 & 0.1887 & 0.2642 & 0.0200 & -0.0182 & -0.0270 & 0.0485 & 0.0058 \\
\hline $\begin{array}{l}\text { Global Competi- } \\
\text { tiveness Index }\end{array}$ & 0.0574 & 0.0444 & 0.0005 & 0.0189 & 0.0142 & -0.0130 & -0.0569 & -0.0385 & -0.0432 & -0.0379 \\
\hline Doing Business & 0.2637 & 0.2671 & 0.2106 & 0.0674 & -0.0203 & 0.0034 & -0.0530 & -0.1963 & -0.2840 & -0.1325 \\
\hline $\begin{array}{l}\text { Index of Economic } \\
\text { Freedom }\end{array}$ & 0.2183 & 0.1797 & 0.2232 & 0.2320 & 0.2375 & -0.0386 & 0.0048 & 0.0136 & 0.0192 & -0.0002 \\
\hline $\begin{array}{l}\text { Human Develop- } \\
\text { mentIndex }\end{array}$ & -0.0314 & -0.0312 & -0.0325 & -0.0318 & -0.0317 & 0.0002 & -0.0011 & -0.0003 & -0.0003 & -0.0004 \\
\hline $\begin{array}{l}\text { Global } \\
\text { Terrorism Index }\end{array}$ & 0.5417 & 0.5920 & 0.6288 & 0.7232 & 0.7713 & 0.0503 & 0.0871 & 0.1815 & 0.2297 & 0.1372 \\
\hline $\begin{array}{l}\text { Corruption } \\
\text { Perception Index }\end{array}$ & 0.1563 & 0.2973 & 0.3421 & 0.3158 & 0.2703 & 0.1410 & 0.1859 & 0.1595 & 0.1140 & 0.1501 \\
\hline
\end{tabular}


Table 5. Overall priority for the area

\begin{tabular}{|c|c|c|c|c|}
\hline $\begin{array}{l}\text { Area assessed by } \\
\text { index / indicator }\end{array}$ & Name of index / indicator & \multicolumn{2}{|c|}{$\begin{array}{l}\text { Group subject to average absolute increase in lacking } \\
\text { proportions }\end{array}$} & $\begin{array}{l}\text { Overall priority } \\
\text { for the area }\end{array}$ \\
\hline 1 & 2 & 3 & 4 & 5 \\
\hline Terrorism & Global Terrorism Index & The biggest increase of gap & 1 & 1 \\
\hline Corruption & Corruption Perception Index & The biggest increase of gap & 1 & 1 \\
\hline \multirow{2}{*}{$\begin{array}{l}\text { Geopolitical situ- } \\
\text { ation }\end{array}$} & Global Peace Index & The biggest increase of gap & 1 & \multirow{2}{*}{1,5} \\
\hline & Fragile States Index & Slight negative growth & 2 & \\
\hline \multirow{3}{*}{$\begin{array}{l}\text { Governance and } \\
\text { legal framework }\end{array}$} & Basel AML Index & Stable with no sizeable changes & 3 & \multirow{3}{*}{2,33} \\
\hline & $\begin{array}{l}\text { Illicit Financial Flows from } \\
\text { Developing Countries }\end{array}$ & Slight negative growth & 2 & \\
\hline & $\begin{array}{l}\text { International Property Rights } \\
\text { Index }\end{array}$ & Slight negative growth & 2 & \\
\hline \multirow{4}{*}{$\begin{array}{l}\text { Economic and so- } \\
\text { cial development }\end{array}$} & Global Competitiveness Index & Improved & 4 & \multirow{4}{*}{3,5} \\
\hline & Doing Business & Improved & 4 & \\
\hline & Index of Economic Freedom & Stable with no sizeable changes & 3 & \\
\hline & Human Development Index & Stable with no sizeable changes & 3 & \\
\hline
\end{tabular}
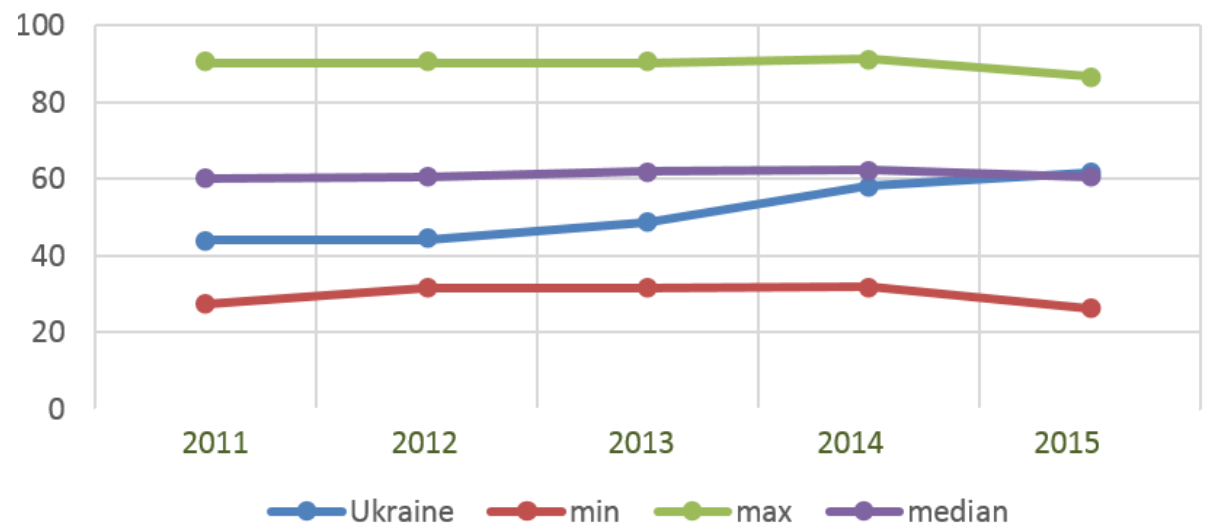

Figure 1. Doing Business Index, 2011-2015

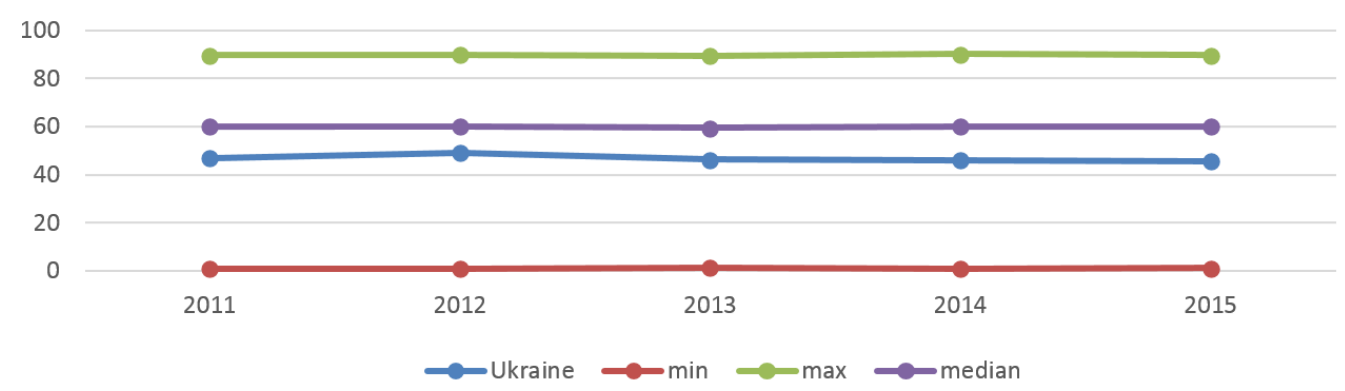

Figure 2. Economic Freedom Index, 2011-2015

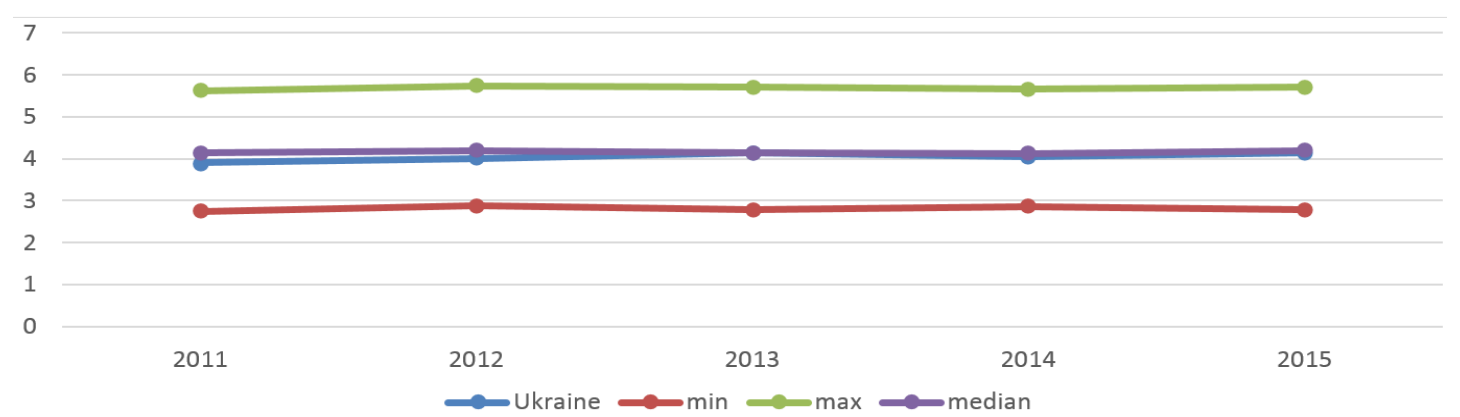

Figure 3. Global Competitiveness Index, 2011-2015 


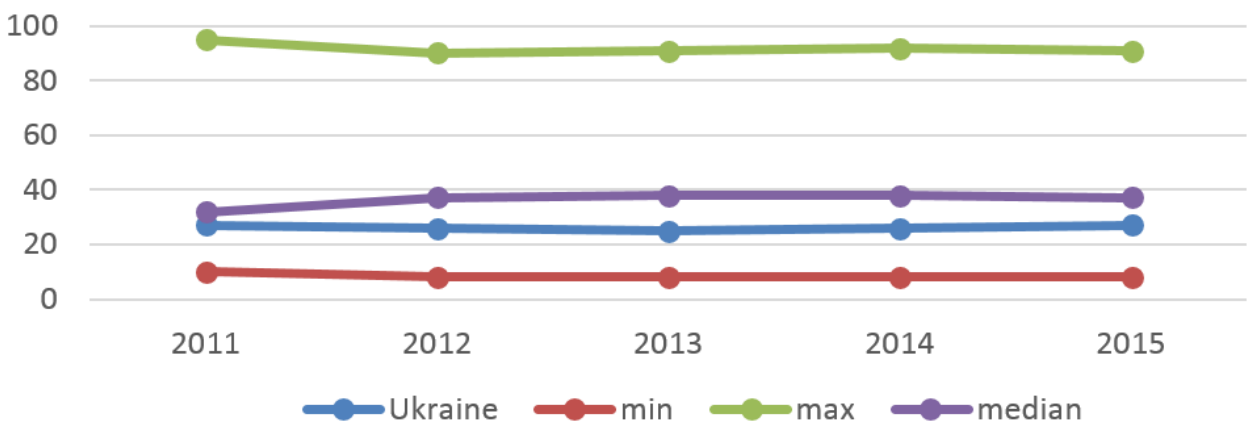

Figure 4. Corruption Perception Index 2011-2015

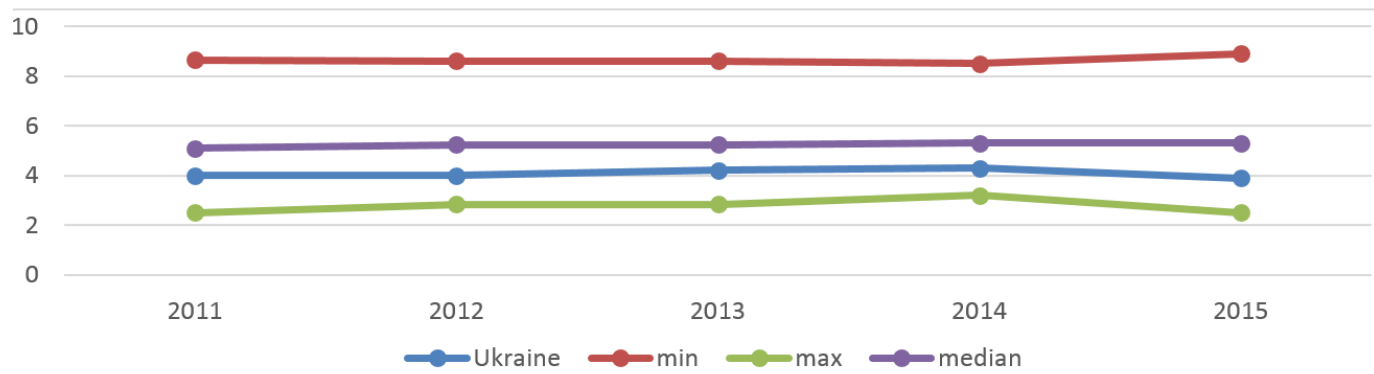

Figure 5. International Property Rights Index, 2011-2015

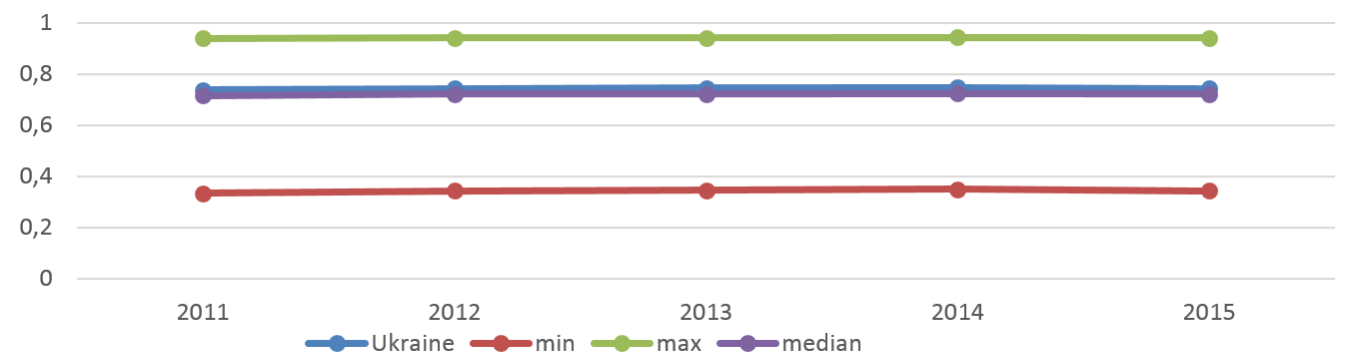

Figure 6. Human Development Index, 2011-2015

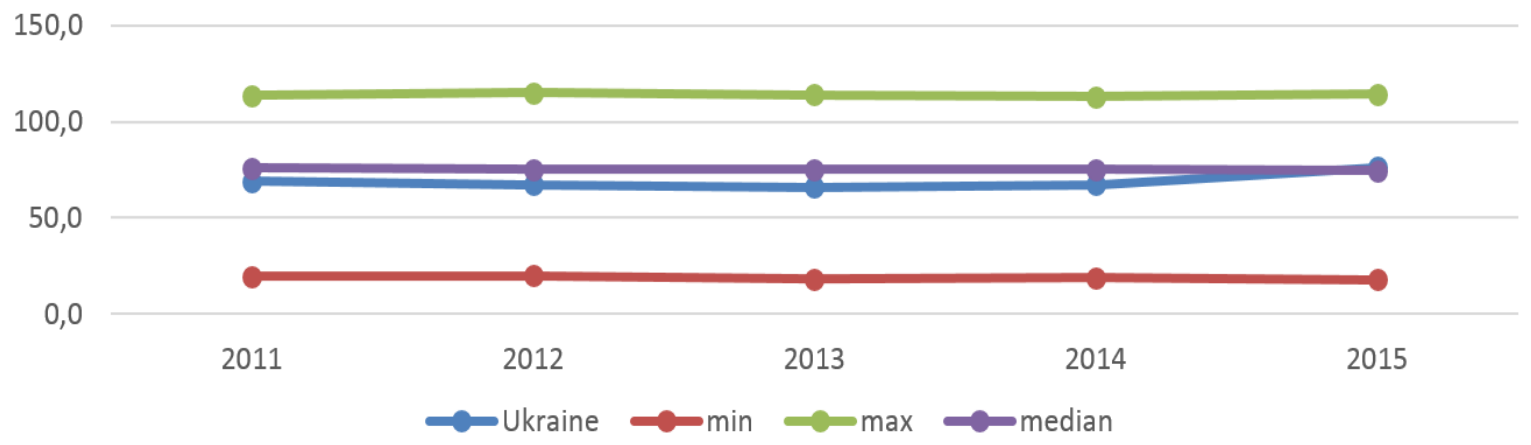

Figure 7. Fragile States Index, 2011-2015 
8

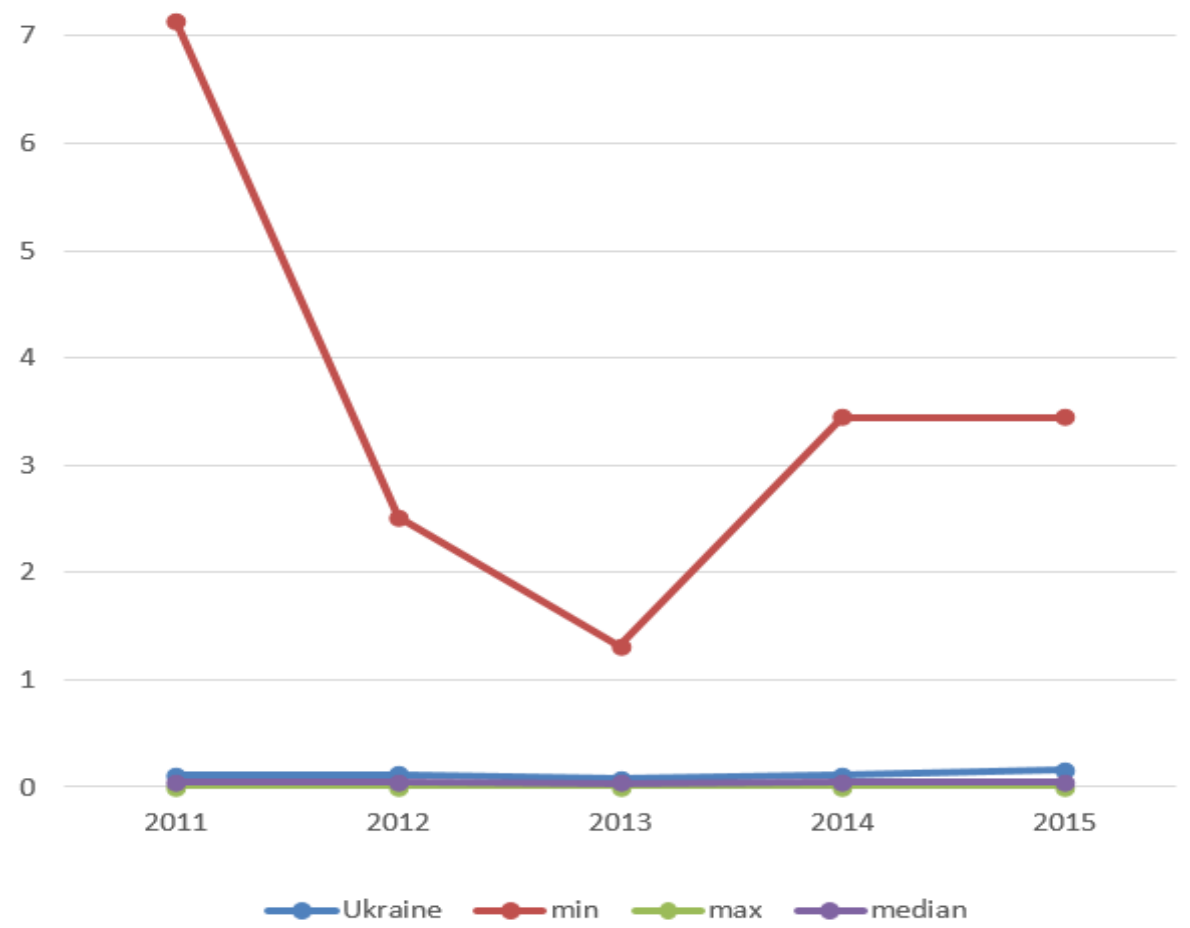

Figure 8. Illicit flows from developing countries to GDP, \% 2011-2015

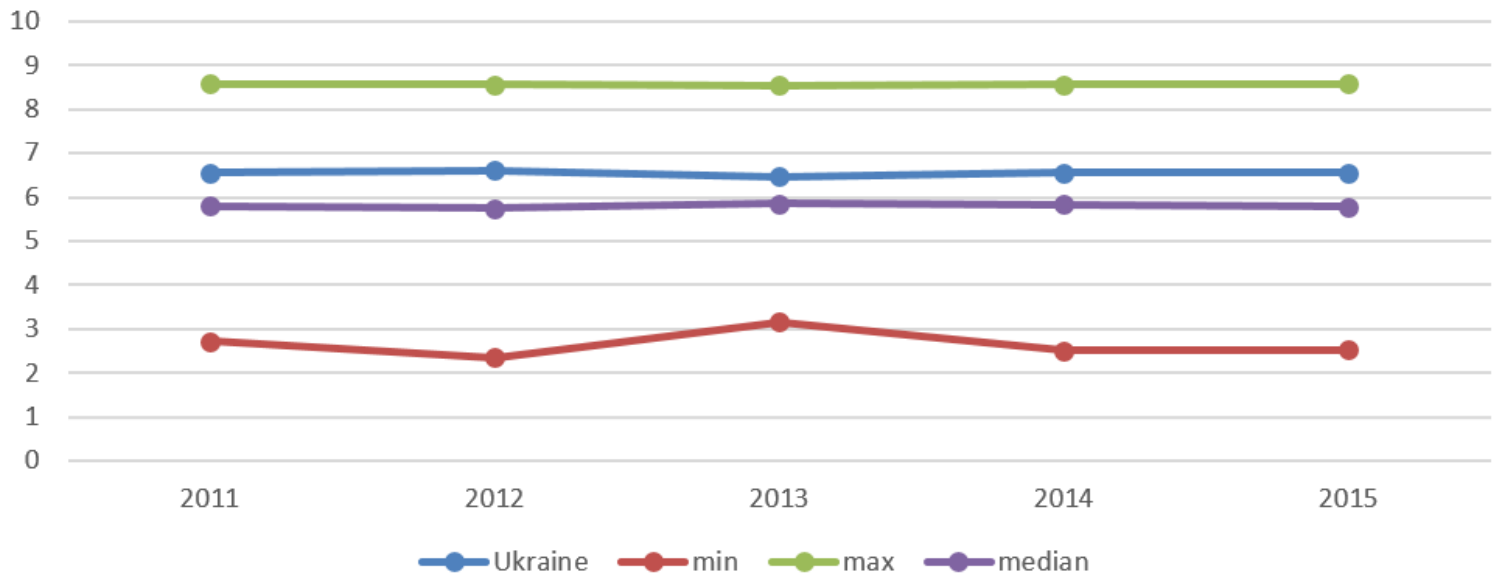

Figure 9. Basel AML Index, 2011-2015

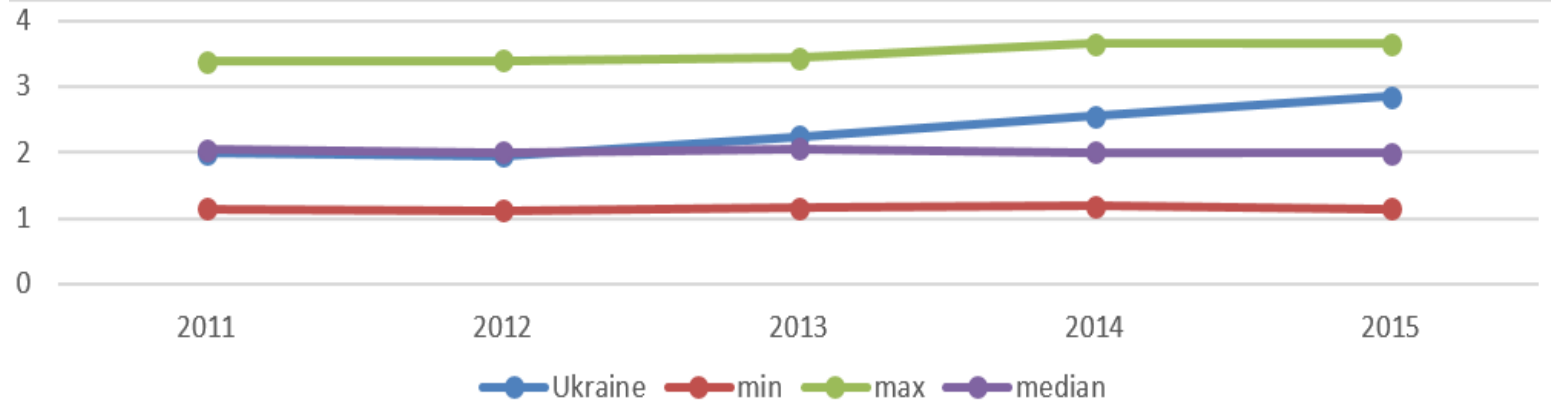

Figure 10. Global Peace Index, 2011-2015 
12

10

8

6

4

0
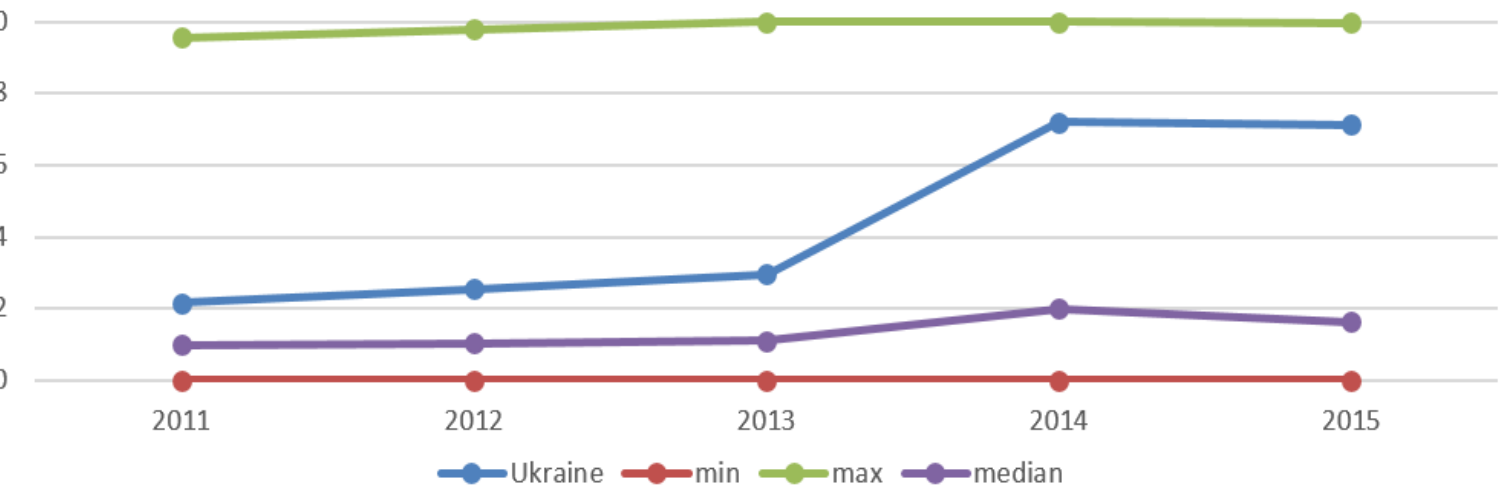

Figure 11. Global Terrorism Index, 2011-2015

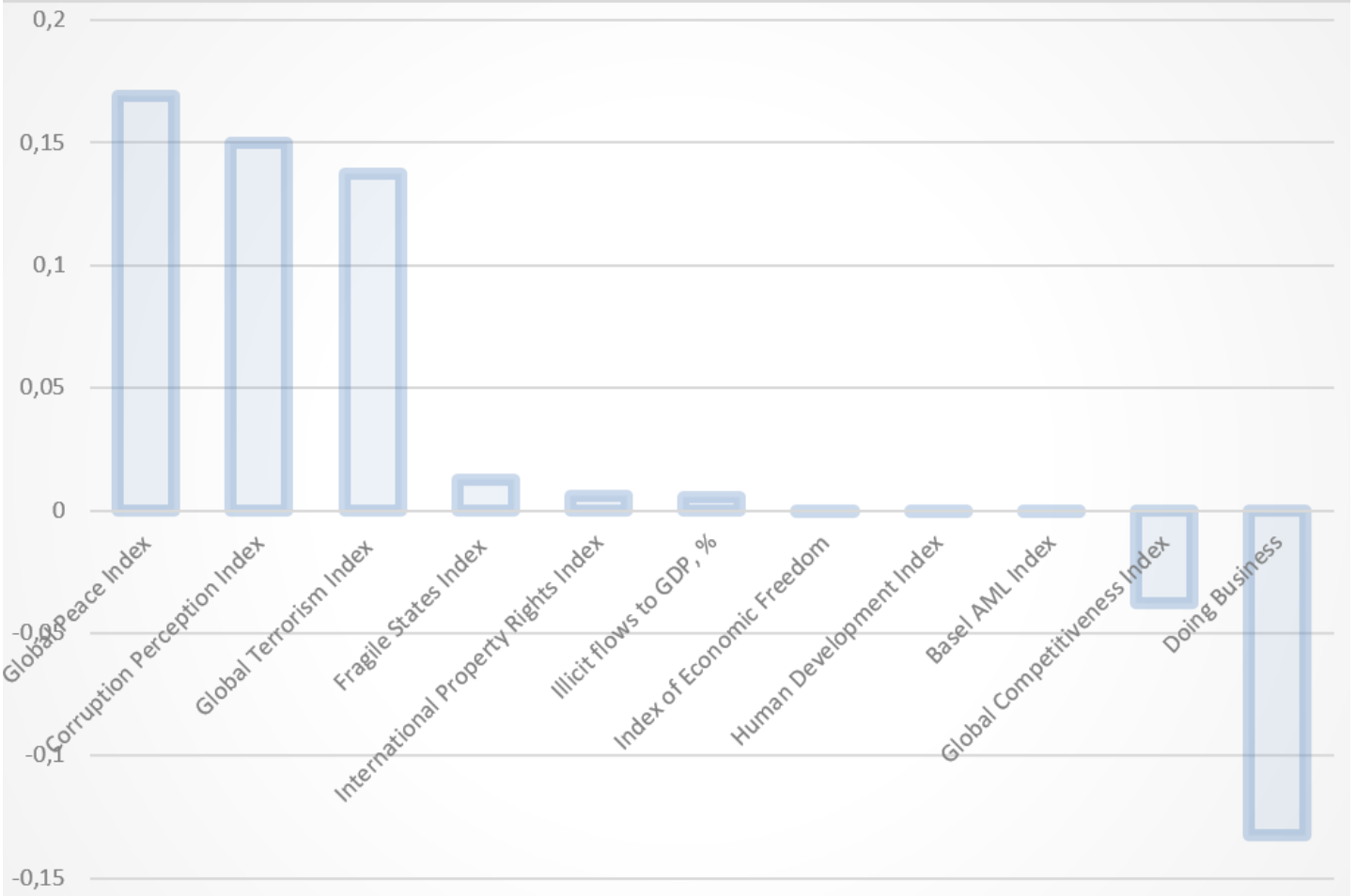

Figure 12. Average absolute increase in lacking proportions for Ukraine 